\title{
AN UPDATE ON SOME DEDUCTIONS, CREDITS AND INCENTIVES IN THE OIL AND GAS INDUSTRY
}

\author{
DAVID W. ROSS*
}

\begin{abstract}
This paper considers varions deductions. credits and incentives available under the Income Tax Act. CEDIP and the Canadian Exploration Incentive Program to those participating in the oil and gas industry. Since this paper was written in May 1988. the draft amendments to the Income Tax Act released on April 13. 1988 and discussed in this paper, have been enacted by S.C. 1988.
\end{abstract} c. 55 .

\section{INTRODUCTION}

This paper addresses the deductions and credits available under the Income Tax Act (Canada) to those participating in the oil and gas industry and includes a brief discussion of the common methods of accessing the same. The final sections of the paper provide a brief overview of the Canadian Exploration and Development Incentive Program and the newly-announced Canadian Exploration Incentive Program.

\section{CANADIAN EXPLORATION EXPENSE}

Canadian Exploration Expense ("CEE") might be said to be an incentive as it is a $100 \%$ deduction.' Expenses which qualify as CEE are pooled in a cumulative CEE account which can be deducted in computing income from all sources by a taxpayer at the end of his taxation year. Where the taxpayer is a "principal-business corporation", 2 there is a requirement that CEE be deducted up to the amount of the taxpayer's income as computed before deductions for CEE, the resource allowance or earned depletion but after deductions allowed in respect of dividends received. ${ }^{3}$ Such taxpayers must deduct these expenses before deducting loss carry forwards from other years.

The items which qualify as CEE all pertain to activities carried on in $\mathrm{Canada}^{4}$ and include the following:

\section{A. SEISMIC EXPENSES}

Geological, geophysical or geochemical expenses incurred by the taxpayer for the purpose of determining the existence, location, extent or quality of an accumulation of petroleum or natural gas. ${ }^{5}$

\section{B. SPECIAL RECOVERY TECHNIQUE EXPENSES}

Any expense incurred after March, 1985 for the purpose of bringing a natural accumulation of petroleum or natural gas into production including clearing, removing overburden and stripping, sinking a shaft or constructing an adit or other

\footnotetext{
Partner, Black and Company, Calgary, Alberta.

1. Income Tax Act, S.C. 1970-71-72-73, c. 63, as am. (referred to herein as "ITA"), s. 66.1.

2. Id. para. $66(15)(\mathrm{h})$.

3. Id. sub-s. $66.1(2)$.

4. Id. s. 255 defines "Canada".

5. Id. sub-para. 66.1(6)(a)(i). This provision actually reads "any expense, including”. Accordingly, costs of an exploratory probe [which is not an oil or gas well as defined in sub-s. 248(1)] would be deductible under this provision. Cf. Fulcrum Resourcess. The Honourable John Zaozirny, Minister of Energy and Natural Resources 45 A.L.R. 315. where seismic is treated as exploration per se.
} 
underground entry, but excluding drilling expenses. This unusual provision is designed to allow taxpayers to claim full CEE on certain costs associated with special oil recovery techniques such as gravity assisted drainage systems. ${ }^{6}$ (Costs of drilling, completion, road construction and site preparation are excluded from this category and are deductible as noted below.)

\section{DRILLING EXPENSES}

Any expense incurred after March, 1987 and in a taxation year of a taxpayer in drilling or completing 7 an oil or gas well in Canada or in building a temporary access road to or preparing a site in respect of such well, provided certain conditions are met:

\section{Discovery}

The well resulted in the discovery of a natural accumulation of petroleum or natural gas and the discovery occurred at any time before six months after the end of the year, or

\section{2. "D \& A"}

The well is abandoned in a year or within six months after the end of the year without ever having produced otherwise than for "specified" purposes, or

\section{Capped And 24 Months}

Expenses in respect of a well pursuant to which there has been no production (other than for "specified" purposes) for a period of 24 months following the day of completion.

A reasonable amount of overhead expenses are usually included in a taxpayer's CEE, although such items must be deducted from that account for purposes of certain deductions permitted pursuant to the Regulations. ${ }^{9}$

\section{PRESCRIBED WELL EXPENSE}

This is defined to mean expenses in respect of a well where a certificate in prescribed form has been filed with the Minister. ${ }^{10}$

Draft legislation released on April 13, 1988 (and enacted on September 13, 1988) indicates that there must be filed with the Minister of National Revenue, within six months after the end of the month in which the drilling of the well commenced, a certificate issued by the Minister of Energy, Mines and Resources certifying that he is satisfied that:

6. Id. sub-para. 66.l(6)(a)(i.1). An "oil or gas well" is defined in sub-s. 248(1) to exclude a well drilled from below the surface of the earth and this provision is designed to permit deduction of certain expenses which might not qualify as well expenses.

7. Il. sub-para. 66.I(6)(a)(ii.l). Dual completions can mean that costs incurred for a well qualify as CEE in some respects and CDE in other respects. It is understood that Revenue Canada now considers "completion" to end when the well is ready for production. This means that expenses incurred for casing. cementing and bringing the well on production are generally CEE or CDE.

8. See definition of "specified purpose", infra $\mathrm{n} .11$.

9. See the discussion of Resource Allowance. infra Part VII.A.

10. Supra n. 1. ITA sub-para. 66.I(6)(a)(ii.l)(D). 
1. the aggregate of expenses incurred shall exceed $\$ 5$ million; and

2. the well will not produce other than for "specified" purposes within 24 months of completion.

The draft legislation released on April 13, 1988 (enacted on September 13, 1988) also indicates that a certificate issued under this section shall become void ab initio if the well does produce (other than for "specified purposes") within 24 months after completion or if any material provided in the application proves to be incorrect.

A "specified purpose" ' means the operation of the well for the sole purpose of testing the well or the wellhead or related equipment in accordance with generally accepted engineering practices; the burning of natural gas or related hydrocarbons to protect the environment; or a prescribed purpose (of which there are none at present).

\section{E. CONVERTED CDE}

Any other expenses which are incurred on wells are considered to be Canadian Development Expenses ("CDE") when initially incurred. However, CDE can be converted to CEE in the following circumstances: ${ }^{12}$

1. an oil or gas well results in a discovery - for example, where the discovery did not result within six months after the end of the particular year the expenses will be considered CDE; if, however, there is a true discovery after that time, then the expenses can be converted to CEE; or

2 . in the period of 24 months commencing on completion, the well has not produced other than for "specified purposes"; or

3. an oil or gas well has never produced and is abandoned. ${ }^{13}$

The conversion to CEE occurs at the time the converting event takes place. In other words, the taxpayer must book the expense as $\mathrm{CDE}$ in the initial year but in the next year, if there has been a discovery, an abandonment of a well or the elapse of the required time without production, the undeducted balance of the expense can then be converted to CEE. ${ }^{14}$

\section{F. BITUMINOUS SANDS DEPOSITS, OIL SANDS DEPOSITS AND OIL SHALE DEPOSITS}

These properties are considered a "mineral resource"1.5 and are subject to certain other requirements. Expenses incurred for the purpose of determining the existence, location, extent or quality of a mineral resource are fully deductible,,$^{16}$ as are the costs of bringing a new mine into production in reasonable commercial quantities if incurred before the coming into production of the new mine. ${ }^{17}$ Such expenses include clearing, removing overburden and stripping, sinking a mine shaft and constructing an adit or other underground entry.

11. Id. sub-para. 66.1(6)(d). For a definition of "production" see para. 66(15)(h.01).

12. Id. sub-para. 66.1(6)(a)(ii.2) and sub-s. 66.1(9).

13. E.g.. if a well is dry but is not abandoned within six months of the end of the year, the expenses incurred in drilling the well become CDE. If the well is abandoned after that time, then the expenses are converted to $C E E$ in the later year.

14. Sipia n. I, ITA sub-s. 66.1(9). But note that "restricted expenses" as defined in para. 66.1(6)(c) are not reclassified. This includes, imer alia, expenses incurred before control of the taxpayer was last acquired.

15. Id. sub-s. $248(1)$.

16. Id. sub-para. 66.1(6)(a)(iii).

17. Id. sub-para. 66.1(6)(a)(iii.l). 


\section{G. CUMULATIVE CEE}

Once a taxpayer has categorized his expenses as CEE, he then adds them to his Cumulative CEE pool. ${ }^{18}$ This pool is reduced by:

l. prior claims;

2. recaptured amounts (e.g. sale of seismic data, the costs of which were originally included in CEE or amounts received as a result of a unitization where initial costs were $\mathrm{CEE}) ;{ }^{19}$

3. the amount of any "assistance" which has been received or which the taxpayer is entitled to receive in respect of CEE or that can reasonably be related to Canadian exploration activities. ${ }^{20}$ For these purposes, "assistance" is defined ${ }^{21}$ to be any amount received or receivable at any time from a person or a government, municipality or other public authority whether such amount is by way of grant, subsidy, rebate, forgiveable loan, deduction from royalty or tax, rebate of royalty or tax, investment allowance or any other form of assistance or benefit. One obvious example of assistance is a payment made under the Canadian Exploration and Development Incentive Program Act. ${ }^{22}$ A less obvious example is a backstop guarantee given by the promoter of a drilling venture which essentially ensures a certain recovery to the investor. The fair market value of such a guarantee would presumably be "assistance" and would reduce the amount of Cumulative $\mathrm{CEE}$;

4. any amounts designated to other taxpayers under the joint exploration corporation rule or amounts transferred to other taxpayers pursuant to successor corporation rules; ${ }^{23}$ and

5. amounts deducted by the taxpayer in respect of investment tax credits which are reasonably attributed to a "Qualified Canadian Exploration Expenditure" as defined for those purposes. ${ }^{24}$

\section{CANADIAN DEVELOPMENT EXPENSE}

Expenses which qualify as Canadian Development Expense ("CDE”) are added to a Cumulative CDE account of which $30 \%$ is deductible on a declining balance tax basis by all taxpayers against all sources of income. In addition, an accelerated deduction is effectively permitted where a taxpayer has sold a Canadian resource property and a portion of the proceeds from the sale becomes credited against his Cumulative Canadian Development Expense pool. ${ }^{25}$

18. Id. para. 66.1(6)(b).

19. Id. sub-ss. $66(12.1)$ and (12.2).

20. Id. sub-para. 66.1(6)(b)(ix).

21. Id. para. 66(15)(a.1).

22. S.C. 1987. c. 18. assented to 25 June 1987 and discussed infra Part XII.

23. Supra n. I. ITA para. 66(10.1)(d) and sub-para. 66.1(6)(b)(xii). Amounts renounced to subscribers for flow-through shares are deemed never to have been CEE of the taxpayer making the renunciation per para. 66(12.61)(b).

24. Id. sub-s. 127(9) and sub-para. 66.1(6)(b)(xi).

25. Where there are no "successored" pools. the proceeds of sale of oil and gas properties are first credited against a taxpayer's Cumulative Canadian Oil and Gas Property Expense pool, and any negative balance is then credited against the taxpayer's Cumulative CDE pool. 


\section{A. QUALIFYING EXPENSES}

The items which qualify as CDE all pertain to activities carried on in Canada and include the following:26

1. expenses incurred in drilling or converting wells in Canada for the disposal of waste liquids from an oil or gas well;

2. expenses in drilling or completing an oil or gas well (to the extent that the expense was not CEE);

3. expenses in building a temporary access road to a well or preparing a site (to the extent that the expense was not CEE);

4. expenses in drilling or converting a well for the injection of water, gas or other substances to assist in the recovery of petroleum or natural gas from another well;

5. expenses in drilling for water or gas for injection into a petroleum or natural gas formation;

6. expenses in drilling or converting a well for the purpose of monitoring fluid levels, pressure changes or other phenomena in an accumulation;

7. expenses incurred in drilling or recompleting an oil or gas well after the commencement of production; and

8. expenses in sinking or excavating or extending a mine shaft, main haulage way or similar underground work designed for continuing use for a mine or a mineral resource after the mine came into production. ${ }^{27}$

\section{B. CUMULATIVE CDE}

Cumulative CDE at the end of a taxation year consists of the taxpayer's accumulated CDE expenses less amounts claimed in prior years, amounts renounced or transferred to other taxpayers pursuant to the joint exploration corporation rules or successor corporation rules, amounts which represent a recapture of CDE expense, amounts which have become CEE and amounts of any "assistance". ${ }^{28}$

\section{CANADIAN OIL AND GAS PROPERTY EXPENSE}

Although Canadian resource properties acquired by investors are not capital properties, the Income Tax Act entitles the purchaser to deduct up to $10 \%$ per annum of the previously undeducted cost of acquiring such properties in recognition of the depleting nature of resource properties.

26. Supra n. 1. ITA para. 66.2(5)(a). It is interesting to note that the cost of purchasing mining properties as opposed to oil and gas properties still merits qualification as CDE and a $30 \%$ declining balance deduction: sub-para. $66.2(5)(a)(i i i)$. Oil and gas properties. as discussed infra, are permitted only a $10 \%$ declining balance deduction.

27. Draft ITA released 13 April 1988 and assented to 13 September 1988 as S.C. 1988, c. 55 (referred to herein as "Draft ITA"), sub-para. 66.2(5)(a)(ii.1). This was formerly included as a Class 12 expense eligible for a $100 \%$ CCA deduction. On the other hand, "designated overburden removal costs" (see Income Tax Regulations, C.R.C. 1978, c. 945, as am. (referred to herein as "ITR"), s.l104(2)] are now to be fully deductible as an operational expense rather that as a Class 12 depreciable property.

28. Supra n. I, ITA para. 66.2(5)(b); the concept of "assistance" is discussed supra, text accompanying n. 20 et seq. 
The cost of purchasing "Canadian resource properties" relating to oil and natural gas $^{29}$ is called a "Canadian Oil and Gas Property Expense" ("COGPE"). ${ }^{30}$ In the context of oil and gas (as distinct from mining) properties, the kinds of Canadian resource property which, when purchased, constitute COGPE include:

1. any right, licence or privilege to explore for, drill for or take petroleum, natural gas or related hydrocarbons in Canada. This encompasses "working interests" which in turn include fee simple interests, ${ }^{31}$ petroleum and natural gas leases and interests held under government-issued drilling permits and exploration agreements;

2. any oil or gas well in Canada or any real property in Canada, the principal value of which depends upon its petroleum or natural gas content (exclusive of depreciable properties used in extraction or removal);

3. any rental or royalty computed by reference to the amount or value of production from an oil or gas well in Canada. This includes lessors' royalties often reserved by owners of a fee simple interest in property when they grant petroleum and natural gas leases, and gross overriding royalties purchased from working interest owners or as part of the consideration received by working interest owners who sell working interests to third parties. Because Canadian courts have given the term "royalty" 32 a meaning broad enough to include most net profits interests and because the definition of "Canadian resource property" requires that a royalty be computed only "by reference to" (and not "as a percentage of") the amount or value of production, it is submitted that "conventional" net profits interests also constitute Canadian resource property. It is understood that this is also the view which is adopted by Revenue Canada, Taxation;

4. the cost of acquiring a right to or interest in any of the above-described properties, other than the right or interest that a taxpayer has by virtue of being the beneficiary of a trust; and

5. net royalty payments to the Saskatchewan Government pursuant to a net royalty petroleum and natural gas lease that was in effect on March 31, 1977, to the extent it can reasonably be regarded as a cost of acquiring the lease.

Specifically excluded from COGPE are any payments made to the Crown for the preservation (as opposed to the acquisition ${ }^{33}$ ) of rights in respect of a Canadian

29. Defined id., para. $66(15)(\mathrm{c})$.

30. Id. para. 66.4(5)(a); see sub-paras. 66(15)(c)(i), (iii) and (iv).

31. Per Cattanach. J. in Alherta and Southern Gas Co. Lud. v. The Queen [1976] C.T.C. 639 at 650.76 D.T.C. 6362 (F.C.T.D.).

32. See Ross v. MNR 50 D.T.C. 775 (Ex. Ct.): Harrington \& Bihler Lid. 67 D.T.C. I (T.A.B.); Saskatchewan Minerals v. Keyes [1972] S.C.R. 703 (S.C.C.); Mr. R. v. MNR 50 D.T.C. 398 (T.A.B.); The Calgary \& Edmomton Corporation Limited v. MNR 54 D.T.C. 353 (T.A.B.): Huffmam v. MNR 54 D.T.C. 383 (T.A.B.); Snyder and Applegate v. MNR I D.T.C. 469 (Ex. Ct.); MNR v. Wain-Tow'n Gas and Oil Company Limited 52 D.T.C. 1138 (S.C.C.): Rebus v. MNR 53 D.T.C. 1237 (Ex. Ct.); J.H. Warsh and Company Limited v. MNR 62 D.T.C. 247 (T.A.B.): Alberta and Southern Gas Co. Lid. v. The Quecn, id.: Rabson Oil Co. Lid. v. Shell Exploration Alberta Lid. (unreported): Skyelands Oils Lud. v. Great Northern Oil Lud. [1976] 5 W.W.R. 370 (Alta. S.C.): Vauban Production v. The Queen 75 C.T.C. 511 (F.C.T.D.): The Queen v. Saint John Shiphuilding \& Dry Dock Co. Lid. 79 C.T.C. 380 (F.C.T.D.); Mercer v. Attomey-General of Omario 5 S.C.R. 538 (S.C.C.). By contrast, under United States law, "royalty" is defined as a "share of production, free of expenses of production": see Williams and Meyers. Mamual of Oil and Gas Terms (Matthew Bender. New York. 1984).

33. The initial bonus paid upon acquiring a petroleum and natural gas lease. whether from the Crown or a freehold owner in fee simple, constitutes COGPE by virtue of being a cost of acquiring a Canadian resource property. See also supra n. I. ITA para. $18(1)(\mathrm{m})$ and supra n. 27. ITR s. 1211. 
resource property (e.g. "delay" rentals) and most rentals, royalties, taxes or bonuses paid to the federal and provincial Crown in relation to the production in Canada of petroleum, natural gas or related hydrocarbons from a mineral resource or oil or gas well in Canada.

All COGPE of a taxpayer is accumulated in a Cumulative COGPE pool. ${ }^{34} \mathrm{~A}$ taxpayer may deduct annually from his income from any source for a taxation year, up to $10 \%$ of his Cumulative COGPE at the end of the taxation year. This deduction, unlike the deduction in respect of Cumulative CEE, ${ }^{35}$ is optional for "principalbusiness corporations" ${ }^{\prime 36}$ as well as other taxpayers. As with the other cumulative deduction pools, Cumulative COGPE is reduced by prior deductions, amounts renounced or allocated or transferred to other taxpayers, certain unitization payments and amounts of any related "assistance".

A full COGPE deduction is effectively permitted to the extent the taxpayer receives or is entitled to receive proceeds from the sale of oil or gas properties.

\section{FOREIGN EXPLORATION AND DEVELOPMENT EXPENSES}

The treatment of Foreign Exploration and Development Expenses ("FEDE") is substantially simpler than the treatment accorded similar expenses incurred in Canada. ${ }^{37}$ All expenses, whether for land, drilling or otherwise, which are incurred in respect of foreign resource properties ${ }^{38}$ are FEDE and the taxpayer may deduct the greater of $10 \%$ of the expenses on a declining balance basis against all sources of income or an amount up to the income derived from foreign resource properties (including proceeds of sale). For these purposes, FEDE includes drilling or exploration expenses, geological expenses, prospecting expenses, costs of acquiring property and any annual payments made for the preservation of the property. FEDE is subject to a reduction where a taxpayer receives an amount and the consideration given by the taxpayer therefor consists of property or services the cost of which may reasonably be regarded as having been primarily FEDE expenses. FEDE deductions are also subject to being transferred under the successor rules. ${ }^{39}$

\section{ADDITIONAL RULES}

The deduction of expenses with respect to CEE, CDE, COGPE and FEDE are subject to additional rules and restrictions.

The terms "outlay" or "expense" are now defined ${ }^{40}$ to exclude any amounts paid or payable as consideration for services or rent, the benefit of which is to be received after that time. Essentially, this means that expenses must be "downhole" before they are eligible. ${ }^{41}$

There are restrictions on the deduction of CEE, CDE, COGPE and FEDE by a corporation where a person or a group of persons has acquired control of the

34. Id. ITA para. $66.4(5)(\mathrm{b})$.

35. Id. para. $66.1(6)(\mathrm{a})$

36. Id. para. $66(15)(\mathrm{h})$.

37. Id. sub-s. 66(4).

38. Id. paras. $66(15)(\mathrm{e})$ and $(f)$.

39. Id. sub-ss. 66.7(2), (10), (11), (13), (15) and (17).

40. Id. para. $66(15)(\mathrm{g} .2)$.

41. This counteracts the decision in Edmonton Liquid Gas 84 D.T.C. 6526 (Fed.C.A.), where the Court found that an expense had been "incurred" where an amount had been paid to an operator before the end of a year but before the work had been completed. 
corporation or the corporation ceases to be tax exempt. ${ }^{42}$ In these situations, the corporation is deemed to be a "successor corporation" that had acquired all of the properties of a predecessor corporation immediately before that time. Generally speaking, this means that the corporation's deductions are restricted - or, in the jargon of the industry, "streamed" - to the extent of the income which is reasonably regarded as being attributable to production from (or proceeds of disposition of) the resource properties owned before the acquisition of control. There are a few exceptions to these rules which apply in narrow circumstances. For one, the corporation may continue to deduct up to $10 \%$ of its FEDE in any given year against income from Canadian resource properties owned before that time. ${ }^{43}$ Additionally, where the corporation has a wholly owned subsidiary, there are provisions which allow the subsidiary to designate income from production from resource properties or from dispositions of the properties to its parent or vice versa. To qualify for this exception, the parent/subsidiary relationship must exist throughout the year and appropriate filings must be made with the Minister of National Revenue. ${ }^{44}$ A similar provision permits the allocation of sourced income between sister corporations which are wholly owned by the same parent. ${ }^{45}$ Pursuant to another exception, a corporation which is a member of a partnership is deemed to own a percentage of the partnership's property and may, therefore, be able to deduct streamed expenses against a portion of the income allocated by the partnership. ${ }^{46}$ Without this provision, a corporation which owned its assets through a partnership might have been precluded from deducting any expenses following an acquisition of control.

It is worth emphasizing that where a corporation does not own resource properties, oil and gas expenses of the corporation effectively disappear upon an acquisition of control unless the narrow exceptions noted above apply. This can occur where the corporation has been allocated expenses either by way of flow-through shares or pursuant to the joint exploration corporation rules.

Where a taxpayer's taxation year is less than 51 weeks, the amount of the deduction determined with respect to FEDE, CDE, COGPE, successored CDE and successored COGPE is reduced in proportion to the length of the taxation year. ${ }^{47}$

There are additional complicating rules where there has been an acquisition of control of a corporate taxpayer by a person or group of persons. ${ }^{48}$ In these situations, if the corporation has acquired property within the 12-month period preceding the acquisition of control, it is deemed not to have acquired the property until the change of control. This anti-avoidance rule is designed to prevent taxpayers from acquiring properties before a change of control and thus avoid the successor rule limitations. However, it should be noted that the rules apply whether or not the taxpayer has an intention to avoid the successor rules and even where the taxpayer does not expect that acquisition of control will occur. To mitigate this rule, it is provided that the rule

42. Supra n. 1, ITA sub-s. 66.7(10). Discussion of the concept of acquisition of control is outside the scope of this paper, but it is worthwhile noting that the Federal Budget of 10 February 1988 proposes that control be determined on a de facto basis as opposed to a de jurc basis for the purpose of the "association" rules. For the purpose of the successor rules, control is still determined on a de jure basis.

43. Id. para. $66.7(10)(f)$.

44. Id. paras. $66.7(10)(\mathrm{g})$ and $(\mathrm{h})$.

45. Id. para. $66.7(10)(\mathrm{i})$.

46. Id. para. $66.7(10)(\mathrm{j})$.

47. Id. sub-s. $66(13.1)$.

48. Id. sub-s. 66(II.4). 
applies only to properties that were acquired from unrelated parties and only where the corporation is not a principal-business corporation. However, the rule also applies to property held in a partnership where the affected corporation is a majority interest partner.

In some cases, an outlay or expense may be properly characterized as either CEE, $\mathrm{CDE}$ or COGPE. In these situations, the taxpayer is only entitled to one deduction, but may make an election as to which provision applies. ${ }^{49}$

In certain situations, the taxpayer will be subject to a special tax on what is known as "carved out income". 50 Where this applies, the taxpayer pays a special $50 \%$ tax, but is then not required to include that amount for purposes of computing income under Part I. ${ }^{51}$ Generally speaking, a practitioner should be wary of any financing arrangements which result in acquisition of a "carved out property". This is essentially a resource property where the amount that the taxpayer is entitled to receive is limited to a maximum amount or is determined by reference to a stated quantity of production from a source. A resource property may be a carved out property if income accrues for a period of time which is less than the lesser of 10 years or the remainder of the term of the head lease. Similarly, where a property is subject to an agreement such that income therefrom reduces substantially after a period of time, the property is considered to be a carved out property. However, there are exclusions which still permit a taxpayer to sell property and to acquire or otherwise retain a reserve or royalty in respect of the sale. In these situations, care must be taken to ensure that the particular provisions of the excepting rules are applicable. ${ }^{52}$

\section{DEDUCTIONS PERMITTED BY REGULATION}

\section{A. RESOURCE ALLOWANCE}

The purpose of the resource allowance is to offset partially certain other inequitable provisions which were enacted in 1974. At that time, the federal government decided that the provinces were reaping too great a benefit from oil and gas royalties on provincial Crown lands and decreed that those royalties must be included in income for federal tax purposes. The federal government was presumably ensuring its participation in these revenues. Eventually, the federal government compromised by enacting the resource allowance provisions. ${ }^{53}$ To generalize, this allows a taxpayer to deduct approximately $25 \%$ of his resource profits from income and will tend to neutralize the inclusion of royalties in income. While a specific calculation must be made in each case, it is generally true that taxpayers paying royalties of less than $25 \%$ tend to receive an overall reduction of taxes from the resource allowance. Taxpayers who have low-royalty properties, who are entitled to royalty holidays or who are recompensed for royalties through the Alberta Royalty Tax Credit could be said to receive an incentive in the form of reduced taxes. The specifics of the resource allowance calculation are as follows:

49. Id. sub-s. $66(13)$.

50. Id. Part XII. I, s. 209. Tax exempt entitics must also beware of Part XII which levies a 33 1/3\% tax on royalties and other payments paid by tax exempt persons where the taxpayer has received "phantom income", e.g. non-deductible Crown royalties.

5I. Id. sub-s. 66(14.6).

52. Id. s. 209.

53. Id. para. 20(1)(v.i) and supra n. 27. ITR s. 1210. 
1. the taxpayer must first calculate his "resource profits" ${ }^{54}$ from oil and gas sources as if those were the taxpayer's only sources of income or loss; ${ }^{55}$

2. when making such a calculation, the taxpayer is not to deduct any rentals or royalties payable to any other taxpayer, including royalties paid to the Crown. with the exception of:

(a) "prescribed" Crown payments, e.g. royalties paid to Her Majesty for the benefit of Indian bands or to Petro-Canada, and Crown rentals payable before commencement of production, ${ }^{56}$ and

(b) royalties known as "production royalties", i.e. royalties which bear a proportion of the Crown royalty; $;^{57}$

3. in making this computation, the taxpayer does not deduct expenses in respect of financing nor expenses for CEE, CDE or COGPE; ${ }^{58}$

4. in making the computation, the taxpayer must reduce his resource profits by the amount of "Canadian Exploration and Development Overhead Expense".59 This term is defined to refer to costs of administration or management in connection with salaries and wages of a person whose duties were not all or substantially all directed towards exploration and development; ${ }^{60}$

5. the taxpayer must deduct from resource profits any rentals or royalties he has received from other taxpayers, unless those royalties are "production royalties" which bear a proportion of the Crown charge; ${ }^{61}$

6. additionally, the taxpayer must deduct certain amounts representing "recaptured" earned depletion base, ${ }^{62}$ and

7. once resource profits are deducted, the taxpayer is then entitled to a $25 \%$ deduction thereof in computing income.

There are numerous issues in calculating resource profits, particularly on the subject of which deductions are "reasonably" applicable to a source of income. There are a number of reassessments which deal with the deduction of scientific research and development expenses, lease rentals for periods prior to production, drilling penalties, freehold delay rentals and salaries paid to shareholder managers.

54. Id. ITR sub-s. 1204(1).

55. Id. sub-para. $1210(\mathrm{I})(\mathrm{a})(\mathrm{i})$.

56. As these royalties are not included in income under either ITA paras. $12(1)(0)$ or $18(1)(\mathrm{m})$, they are excluded from the resource profits calculation. ITR s. 1211 enumerates various Crown payments which are deductible. This includes up to $\$ 2.50$ per hectare per year of lease rentals prior to taking petroleum or natural gas and amounts paid under s. 49 of the Canada Oil and Gas Act, S.C. 1980$81-82-83$, c. 81 , as am.

57. Supra n. 27, ITR sub-para. 1210(1)(a)(i)(A) and sub-s. 1206(1). At the present time, a taxpayer does not deduct royalties paid on tar sands production, as those are considered mining royalties rather than oil and gas royalties. The Budget of 10 February 1988 proposed that tar sands production be treated the same way as oil and gas production for these purposes.

58. Id. sub-paras. $1210(1)(\mathrm{a})(\mathrm{i})(\mathrm{B})$ and $(\mathrm{C})$.

59. Id. sub-para. $1210(1)(\mathrm{a})(\mathrm{ii})$.

60. Id. sub-s. 1206(1).

61. Id. sub-para. 1210(1)(a)(iii).

62. Id. para. $1210(1)(\mathrm{b})$. This means the amount, if any, by which amounts determined under ITR paras. $1205(1)(\mathrm{e})$ to $(\mathrm{k})$ exceed $33 \mathrm{I} / 3 \%$ of the amounts determined under ITR paras. 1205(I)(a) through (d.1). 


\section{B. DEPLETION}

In accounting argot, the word "depletion" normally refers to a form of depreciation which is taken against depleting assets. In other words, to the extent that oil is produced from an oil well, the asset is said to deplete and accounting rules require that the financial records disclose such depletion.

For many years, the Income Tax Act has provided its own set of rules which allow taxpayers a form of depletion. ${ }^{63}$ While an earned depletion allowance is still allowed with respect to a few items, generally speaking the federal government has determined that a depletion allowance is unnecessary, as taxpayers are allowed to deduct the full capital costs of oil and gas properties pursuant to other provisions. Accordingly, the depletion allowance is being phased out and at present it appears unlikely that it will be restored.

The earned depletion allowance generally permitted a deduction equal to the lesser of the taxpayer's earned depletion base as at the end of the year and the aggregate of $25 \%$ of the taxpayer's "resource profits" for the year. As can be seen, this requires determination of two items, earned depletion base and resource profits. ${ }^{64}$

At the present time, amounts which are added to a taxpayer's earned depletion base are very limited in scope as far as the oil and gas industry is concerned, as a taxpayer is only able to earn additional earned depletion base with respect to qualifying earned expenditures on a "tertiary recovery project". The rate of inclusion of $331 / 3 \%$ of such expenditures is to be reduced to $162 / 3 \%$ with respect to expenditures incurred after June 30th, 1988 and before $1990 .^{65}$

A "qualified tertiary oil recovery project" is defined ${ }^{66}$ to mean a project that uses a method designed to recover oil from an oil well in Canada that is incremental to oil that would be recovered by a primary or secondary method. These techniques include use of carbon dioxide miscible, hydrocarbon miscible, and thermal or chemical processes, but exclude any "secondary recovery method"67 ( such as waterflooding).

The earned depletion base is reduced by deductions therefrom and by certain recaptured amounts. ${ }^{68}$

\section{CAPITAL COST ALLOWANCES}

The typical capital cost allowance ("CCA") classes of the depreciable property components of an upstream oil and gas business are set forth below:

63. Id. s. 1201 .

64. Id. paras. 1201 (a) and (b).

65. Draft Regulation dated I3 April 1988, s. 1205. An announcement made by the Minister of Finance on 3 May 1988 proposed to extend the Mining Exploration Depletion Allowance but not "Earned Depletion".

66. Supra n. 27, ITR s. 1206.

67. Id.

68. Id. paras. $1205(1)(\mathrm{e})$ to (j). 


\section{TABLE 1 \\ 1987 AND PROPOSED 1988 CCA RATES}

\begin{tabular}{|c|c|c|c|c|}
\hline & & & & PROPOSED \\
\hline OLD & NEW & & 1987 & 1988 \\
\hline CLASS & CLASS & DESCRIPTION & CCA RATE & CCA RATE \\
\hline 10 & 41 & $\begin{array}{l}\text { Drilling rigs, and gas or } \\
\text { well equipment }\end{array}$ & $30 \%$ & $25 \%$ \\
\hline 7 & 41 & Offshore drilling vessels & $30 \%$ & $25 \%$ \\
\hline 8 & 8 & $\begin{array}{l}\text { Pipelines other than those included } \\
\text { in Class } 1 \text { or } 2 \text { (including gathering } \\
\text { systems in an oil or gas field where } \\
\text { it is likely the resource will be } \\
\text { exhausted within } 15 \text { years) }\end{array}$ & $20 \%$ & $20 \%$ \\
\hline 2 & 1 & Other pipelines & $6 \%$ & $4 \%$ \\
\hline 28 & 41 & New oil sands plants & $\begin{array}{l}30 \% \text { plus } \\
\text { project }\end{array}$ & $\begin{array}{l}25 \% \text { plus } \\
\text { project }\end{array}$ \\
\hline & & & $\begin{array}{l}\text { income } \\
\text { resource } \\
\text { allowance, } \\
\text { depletion, }\end{array}$ & $\begin{array}{l}\text { income } \\
\text { resource } \\
\text { allowance, } \\
\text { depletion, }\end{array}$ \\
\hline & & & $\mathrm{CEE}$ and $\mathrm{CDE}$ & $C E E$ and $C D E$ \\
\hline
\end{tabular}

The allowable CCA deduction in the year that an asset is acquired is one-half the amount normally allowed ${ }^{69}$ and new rules proposed in the Tax Reform White Paper of June 18, 1987 will postpone deductions until the asset is put in use for property acquired after 1989. Draft Regulations published on December 16, 1987 indicate that property will not be considered to fall into one of the new classes by reason of a nonarm's length disposition and similar rules will apply where property is deemed to be disposed of on an acquisition of control. These Regulations also indicate that a taxpayer may avoid recognition of recapture with respect to an "old" class by deducting amounts from a new class.

Allocations of purchase price as between petroleum and natural gas rights on the one hand (i.e. COGPE) and the related depreciable assets on the other (i.e. CCA) in agreements of purchase and sale of producing working interests seem to range between $2 \%$ and $90 \%$ for the depreciables, with perhaps $20 \%$ being the norm. Since CCA rates for all classes of oil and gas-related depreciable assets other than Class 2 assets exceed the rate of deduction allowed for Cumulative COGPE, purchasers will desire to allocate as high a portion of the purchase price as possible to the depreciable assets. There should be an allocation of price as between the various CCA classes as well. While the Supreme Court of Canada judgment in Golden v. The Queen ${ }^{70}$ does not entitle arm's length parties to negotiate and agree upon any allocation whatsoever between petroleum and natural gas rights and the related depreciable 
assets, it may be difficult for Revenue Canada to question the reasonableness of this allocation in most cases. It is obvious, as well, that the applicable tax rates actually impact on the relative values of the assets. Allocations may also have serious implications relative to the conveyance of the assets and any rights of first refusal.

\section{INVESTMENT TAX CREDITS}

\section{A. QUALIFIED CANADIAN EXPLORATION EXPENDITURES}

There is a special investment tax credit permitted for "Qualified Canadian Exploration Expenditures". ${ }^{71}$ As a rough guideline, expenditures incurred in drilling oil or gas wells which exceed $\$ 5$ million are eligible for this credit. Pursuant to draft legislation tabled in the House of Commons on April 13, 1988 (enacted on September 13,1988 ), corporations will be able to deduct three-quarters of their investment tax credit from federal taxes payable in any given year. A Canadian-controlled private corporation will be able to deduct the full tax credit to the extent of taxes on income eligible for the small business deduction. ${ }^{72}$

"Qualified Canadian Exploration Expenditures" are defined only by draft Regulations at the present time. ${ }^{73}$ Specified expenses in excess of a "base amount"74 are eligible for the investment tax credit. For these purposes, a "base amount" is in turn defined by reference to certain specified expenses in excess of a "threshold amount". ${ }^{75}$ For these purposes, the threshold amount is $\$ 5$ million or the amount allocated to the taxpayer where the cost of such a well is shared among taxpayers either directly, through a Joint Exploration Corporation or pursuant to a flow-through share arrangement. An agreement must be filed with the Minister allocating such expenses among taxpayers. ${ }^{76}$ The definition of specified expenses is a little more complicated, as there is one definition given in respect of an "exploratory probe" and another in respect of oil or gas wells. ${ }^{77}$ Briefly stated, expenses which qualify as CEE are generally eligible for these purposes if they are incurred before 1991 and are not "nonqualifying expenses". This latter term is also defined in the Regulations ${ }^{78}$ and refers to expenses which can reasonably be regarded as being incurred for consideration for services to be rendered after 1990, Canadian Exploration and Development Overhead Expenses ${ }^{79}$ or as expenses otherwise eligible for a Petroleum Incentives Program grant.

There are relieving provisions found in these Regulations that contemplate a disruption in drilling. If a well has to be abandoned because of geological or mechanical difficulties and a new well is drilled which can reasonably be regarded as a replacement for that well, then the cost of both wells can be added into the expenses eligible for this purpose ${ }^{80}$ These investment tax credits reduce the amount of a taxpayer's deductible CEE. ${ }^{81}$

71. Draft ITA released 13 April 1988 and enacted on 13 September 1988 as S.C. 1988, c. 55 (referred to herein as "Draft ITA"), sub-ss. 127(5) and (9), and supra n. 65. Draft ITR s. 4609.

72. Id. Draft ITA sub-ss. 127(5) and (9).

73. Supra n. 65. Draft ITR s. 4609.

74. Id. sub-s. $4609(2)$.

75. Id. sub-ss. $4609(6)$ and (7).

76. Id. sub-s. $4609(7)$.

77. Id. sub-ss. 4609(3) and (4).

78. Id. sub-s. 4609(5).

79. Supra n. 27, ITR sub-s. 1206(1).

80. Supru n. 65. Draft ITR sub-s. 4609(9).

81. Supra n. 1. ITA sub-para. 66.1(6)(b)(ix) and para. 66(15)(a.l ). 


\section{B. OTHER INVESTMENT TAX CREDITS}

The rate of investment tax credit which is earned on qualifying property has gradually been decreasing over the last few years. Draft legislation tabled April 13, 1988 (enacted on September 13, 1988) indicates that the rate will be $15 \%$ in respect of property acquired after 1988 for use in Atlantic Canada, 30\% in respect of "certified property" acquired after 1988 and $45 \%$ in respect of approved project property acquired after 1988 for use in Cape Breton. ${ }^{82}$ Qualifying property acquired for use in other areas of Canada will be eligible for a 3\% investment tax credit in 1988 but nothing thereafter. ${ }^{83}$ An investment tax credit of $20 \%$ of the expenses which qualify for scientific research and experimental development is still permitted, such credit being 30\% when incurred in the Provinces of Newfoundland, Prince Edward Island, Nova Scotia and New Brunswick or in the Gaspé Peninsula. ${ }^{84}$

The categories of property which qualify for investment tax credit are "qualified property", "qualified transportation equipment" and "qualified construction equipment", 85 and enhanced credits are available with respect to "certified property" and "approved project property". All of these definitions refer to properties as described in the Regulations and which are "brand new" when acquired and are used either for lease or in a designated activity. ${ }^{86}$ The designated activities normally include the construction business, manufacturing or processing, operating an oil or gas well, extracting minerals, processing tar sands, exploring or drilling for petroleum or natural gas, and the like. The Regulations, which then detail the property which is prescribed, cross-reference various Capital Cost Allowance classes and it is necessary to determine with respect to each property whether it is qualified for purposes of the Regulations.

There are many other rules which govern investment tax credit claims and which cannot be fully detailed in this paper. A few of the noteworthy rules are: the reduction of Capital Cost Allowance for depreciable properties to the extent amounts are claimed for investment tax credits; ${ }^{87}$ the "streaming" of investment tax credits where control of a corporation is acquired by a person or a group of persons within a year ${ }^{88}$ and the ability to carry investment tax credits back 3 years and, pursuant to new draft legislation, forward 10 years; ${ }^{89}$ special incentives with respect to Canadian-controlled private corporations; and the reduction of the basis on which the credit is calculated by reference to any government or non-government assistance. ${ }^{90}$

82. Supra n. 71, revisions to para. (a) of the definition of "specitied percentage" in sub-s. 127(9).

83. Sub-para. (a)(vii)(D) of the current definition of "specified percentage" in supra $n$. I. ITA sub-s. 127(9).

84. Para. (e)(iv) of the current definition of "specified percentage" in id.. ITA sub-s. 127(9). See also sub-ss. $127(10.1)$ to (10.4), which provide for an additional credit for Canadian-controlled private corporations.

85. Id. sub-s. 127(9). As to "ancillary" property, sce Noranda Mines Ltd. 87 D.T.C. 153 (T.C.C.).

86. Id. sub-s. 127(9) and supra n. 27. ITR Part XLVI. s. 4600 "qualified property" [see also ITA sub s. 127(11)]: ITR s. 4601 "qualified transportation equipment": ITR s. 4602 "certified property": ITR s. 4603 "qualified construction equipment": and ITR s. 4604 "approved project" and "approved project property". As to use of property by sub-contractors, se' Loj-We's Contracting Lta. 8.5 D.T.C. 5310 (Fed.C.A.).

87. Supra n. I, ITA sub-s. 13(7.1) and supra n. 71, Draft ITA sub-s. 13(7.1); see also ITA paras. $53(2)(\mathrm{c}),(\mathrm{h})$ and $(\mathrm{k})$ and sub-s. 127(12.2).

88. Id., ITA sub-s. 127(9.2).

89. Definition of "investment tax credit" in supra n. 71, Draft ITA sub-s. 127(9).

90. Supra n. I, ITA sub-s. $127(11.1)$. 
One of the problems with investment tax credits is that a taxpayer has to make money and be taxable before the credit has any value. To make this incentive more worthwhile, the government introduced the concept of refundable investment tax credits in 1985. This was proposed for elimination in the White Paper of June, 1987 and now, pursuant to terms of draft legislation tabled April 13, 1988 (enacted September 13,1988 ), is to be restricted to individuals and qualifying corporations. Only corporations which are small business corporations earning less than $\$ 200,000$ in the preceding year (in conjunction with all associated corporations) will be qualified. The refundable portion of investment tax credits is limited to $40 \%$ thereof.91

\section{OTHER TAX CREDITS}

There are other tax credits which provide incentives, albeit ones which are not specifically directed at the oil and gas industry. The small business deduction applies to the first $\$ 200,000$ of active income of a Canadian-controlled private corporation ${ }^{92}$ and the manufacturing and processing credit applies to a corporation's Canadian manufacturing and processing profits for the year. ${ }^{93}$

The following chart indicates basic corporate income tax rates before the $3 \%$ federal surtax expected to be effective as of July 1, 1988:

TABLE 2

BASIC CORPORATE INCOME TAX RATES

(WITHOUT SURTAX)

$\begin{array}{lccc} & \text { ALBERTA } & \text { FEDERAL } & \text { COMBINED } \\ \text { Small Business M \& P } & 0 \% & 12 \% & 12 \% \\ \text { Small Business General } & 5 \% & 12 \% & 17 \% \\ \text { Corporate M \& P } & 9 \% & 26 \% & 34 \% \\ \text { General Corporate } & 15 \% & 28 \% & 43 \%\end{array}$

\section{SCIENTIFIC RESEARCH AND EXPERIMENTAL DEVELOPMENT}

Expenses or expenditures on scientific research and experimental development would normally not be deductible unless it could be shown that they were incurred for the purpose of earning income. However, section 37 permits a 100\% deduction of some of these amounts where various conditions are met. An analysis of these rules is outside the scope of this paper, but it is worth noting that significant revisions to these rules are now contained in draft legislation tabled April 13, 1988 (enacted on September 13,1988). Most notable are the new requirements which allow deduction only where the expenses are related to a business of the taxpayer in which he was actively engaged at the time he incurred the expenses.

91. Supra n. 71, Draft ITA s. 127.1.

92. Supra n. I, ITA s. 125.

93. This latter credit is not applicable to operating an oil or gas well. but will include profits from gas processing activitics and sulphur processing: see ITA s. 125.1. 


\section{PRESENT VALUE OF DEDUCTIONS}

While there are many assumptions which have to be made in order to determine the present value of a deduction, it is sometimes helpful to have a rough idea of the present value of a particular deduction. The following tables present such guidelines:

TABLE 3

COGPE (10\%)
PERCENTAGE

RATE OF RETURN'

10

12

15

18

20

PERCENTAGE

RATE OF RETURN'

10

12

15

18

20

\begin{tabular}{llll} 
& \multicolumn{3}{c}{ TAX RATE $^{2}$} \\
$25 \%$ & $45 \%$ & $50 \%$ & $55 \%$ \\
\hline 11.14 & 20.05 & 22.28 & 24.51 \\
10.41 & 18.75 & 20.83 & 22.92 \\
9.46 & 17.04 & 18.93 & 20.83 \\
8.65 & 15.58 & 17.31 & 19.03 \\
8.17 & 14.71 & 16.35 & 17.98
\end{tabular}

TABLE 4

CDE (30\%)

\begin{tabular}{lllll} 
& $25 \%$ & $45 \%$ & $50 \%$ & $55 \%$ \\
\cline { 2 - 5 } 10 & 18.24 & 32.83 & 36.48 & 40.13 \\
12 & 17.33 & 31.19 & 34.66 & 38.13 \\
15 & 16.10 & 28.98 & 32.20 & 35.42 \\
18 & 15.00 & 27.01 & 30.01 & 33.01 \\
20 & 14.34 & 25.81 & 28.68 & 31.54
\end{tabular}

TABLE 5

CLASS 8 (20\% CCA)

PERCENTAGE

RATE OF RETURN'

10

12

15

18

20
TAX RATE?

\begin{tabular}{llll}
$25 \%$ & $45 \%$ & $50 \%$ & $55 \%$ \\
\hline 15.60 & 28.08 & 31.20 & 34.32 \\
14.67 & 26.40 & 29.33 & 32.27 \\
13.42 & 24.16 & 26.84 & 29.53 \\
12.33 & 22.20 & 24.66 & 27.13 \\
11.68 & 21.03 & 23.37 & 25.70
\end{tabular}


TABLE 6

CLASS 41 (25\% CCA)

PERCENTAGE

RATE OF RETURN'

10

12

15

18

20

\begin{tabular}{cccc}
\multicolumn{4}{c}{ TAX RATE $^{2}$} \\
$25 \%$ & $45 \%$ & $50 \%$ & $55 \%$ \\
\hline 17.12 & 30.83 & 34.26 & 37.68 \\
16.19 & 29.15 & 32.39 & 35.62 \\
14.93 & 26.88 & 29.87 & 32.86 \\
13.82 & 24.89 & 27.66 & 30.42 \\
13.16 & 23.68 & 26.32 & 28.95
\end{tabular}

Notes apply to all four tables:

1. Discount rate is calculated on a monthly basis for ten years.

2. This is a marginal rate. If a particular deduction impacts on the resource allowance so as to reduce or increase the marginal rate. further calculation would be required.

\section{ACCESS TO DEDUCTIONS AND CREDITS}

\section{A. FARM-INS}

The farm-in is a common method of acquiring an interest in oil and gas properties. Rather than purchasing an interest directly, the "farmee" agrees to incur CEE and/or $\mathrm{CDE}$ on property in which the "farmor" has a working interest. As consideration for incurring these expenditures, the farmee "earns" a royalty interest or an undivided working interest in the lands and often in an area surrounding the lands enhanced by the farmee's expenditures. The terms of the farm-in are negotiated, typically with a greater interest being earned per dollar of expenditure on unexplored lands than on lands near already developed acreage.

As set out in its Interpretation Bulletin IT-125R3, Revenue Canada, Taxation treats the farmor as having disposed of a resource property for nil proceeds. The farmee is considered to have incurred $\mathrm{CEE}$ and/or CDE, depending on the nature of the expenditures, rather than having incurred a combination of CEE, CDE and COGPE. The farmee's position might be said to have some statutory foundation in subsection 66(13).

Revenue Canada, Taxation has become concerned that taxpayers have interpreted its farm-in policy more broadly than was intended, and have engaged in farmins in which a farmee earns an interest in unrelated producing oil and gas properties or in non-resource properties (e.g. tangible depreciable assets). It is understood that Revenue Canada, Taxation regards farm-in treatment as being available only where the farmee earns an interest in a non-producing resource property whether or not contiguous to the lands on which the farmee incurs CEE and/or CDE. ${ }^{94}$ For this purpose, capped gas wells will be treated the same as producing oil and gas wells. In any other case, the transaction (called a "widespread" farm-in) will be assessed as follows:

94. Revenue Canada. Taxation. "Opinion to Canadian Petroleum Association of April 12, 1985". Revenue Canada had indicated that it would issue a definitive statement on the issue but has never done so. 
1. the farmee will be considered to have an amount receivable for the purpose of subsection 66(12.1) equal to the fair market value of the property received and his Cumulative $\mathrm{CEE}$ or Cumulative $\mathrm{CDE}$ will be reduced proportionately with such amount being considered as COGPE to the farmee; and

2. the farmor will be regarded as having disposed of the property for proceeds equal to its fair market value, and as having incurred CEE or CDE in an equivalent amount.

This represents a change from Revenue Canada, Taxation's position as expressed at the 1979 Round Table discussion, in which farm-in treatment was stated as applying only where "the property in which an interest is being surrendered is the property which will be potentially enhanced in value as a result of the exploration and development work". ${ }^{95}$

It is essential in structuring farm-ins to ensure that the farmee clearly incurs the $\mathrm{CEE}$ and/or CDE itself, as opposed to reimbursing the farmor for expenditures incurred by him. In the latter case, the CEE and CDE deductions can be claimed only by the farmor, and the farmee will incur only COGPE. ${ }^{96}$

\section{B. JOINT EXPLORATION CORPORATION}

The use of a "Joint Exploration Corporation" ("JEC") enables the risks inherent in drilling operations to be isolated in the JEC rather than exposing the parent corporation's assets to those risks. At the same time, to the extent the parent funds the resource expenditures of the JEC, ${ }^{97}$ the parent can deduct all the CEE, CDE and COGPE incurred by the JEC using the funds invested by the parent. ${ }^{98}$ The JEC's entitlement to other deductions, such as Foreign Exploration and Development Expenses ("FEDE"), CCA and resource allowance cannot, however, be utilized by the parent.

Certain deductions may be transferred pursuant to the joint exploration corporation rules. ${ }^{99} \mathrm{~A}$ corporation will qualify as a JEC so long as it confines itself to certain resource-related activities. ${ }^{100}$ A JEC may be a corporation either resident or not resident in Canada, as may the parent corporation to which the JEC renounces its resource deductions.

Payments made by a shareholder to fund the JEC's resource expenditures may be invested in the JEC as debt or equity. Because the amount of any resource deduction renounced by a JEC reduces the adjusted cost base of the parent's investment, ${ }^{101}$ there is a risk of triggering an unintended capital gain on repayment of a loan made by a

$95 \quad 1979$ C.R. 637.

96. See Farmers Mutual Petroleums Lid. v. MNR 21 D.T.C. 5277 (S.C.C.).

97. Supra n. I, ITA paras. 66(15)(a) and (i).

98. Id. sub-ss. 66(10). (10.1), (10.2), (10.3) and (10.4).

99. Id.

100. Id. para. $66(15)(\mathrm{g})$. A joint exploration corporation must not have had. at any time since its incorporation, more than 10 sharcholders (excluding persons holding shares in order to qualify as directors) and must be a "principal-business corporation" as defined in ITA para. $66(15)(h)$. Se' MNR v. Consolidated Mogul Mines Limited 66 D.T.C. 5008 (Ex. Ct.), affal. 68 D.T.C. 5284 (S.C.C.); and Sogemines Development Company Limited v. MNR 72 D.T.C. 62.54 (F.C.T.D.), affal. 73 D.T.C. 5304 (Fed.C.A.); American Meral Co. of Canada Lad. 52 D.T.C. 1180 (Ex. Ct.): Dillman Oil Property LId. v. MNR 66 D.T.C. 2: MWA Gas \& Oil Lid. v. MNR 74 D.T.C. 6123 (F.C.T.D.): Alberta and Southern Gas Co. Lid., supra n. 31; Ethyl Corp. of Canada Lud. v. The Queen 79 D.T.C. 5012 (F.C.T.D.): and Interpretation Bulletin IT-400.

10I. Supra n. I, ITA paras. 53(2)(f), (f.1) and (f.2). 
parent to a JEC. It is generally preferable for the funds provided to the JEC to be paid as consideration for the issuance of preferred shares ${ }^{102}$ of a separate class or series ("JEC preferred shares") having nominal paid-up capital, or by way of a contribution of capital (i.e. a payment for which the parent receives no consideration). If the parent receives shares of a class it already owns, an unintended capital gain may result if the cost of all shares is averaged down pursuant to section 47 and the cost of the particular shares issued for JEC purposes is reduced pursuant to subsection 66(10.4) and paragraph $53(2)(f .1)$ or (f.2). JEC preferred shares will normally have a reduced adjusted cost base, which will not be averaged with the cost base of shares of other series and classes in the JEC and, accordingly, will not inhibit redemption of such other shares or the reduction of their paid-up capital by triggering a capital gain. Provided that JEC preferred shares themselves have nominal paid-up capital, they can in some circumstances be redeemed tax-free provided that both the parent and JEC are taxable Canadian corporations. The contribution of surplus will, as between a parent and JEC, both of which are taxable Canadian corporations, enable dividends to be paid by the JEC without triggering a capital gain.

The foregoing comments concerning the tax-free redemption of JEC preferred shares and the payment of tax-free dividends do not apply in cases where subsection 55(2) applies, for example, where surplus is being stripped from the JEC in contemplation of an investment in the JEC being made by an arm's length third party or where other anti-avoidance rules are applicable. A proposed redemption of shares and payment of dividends must now be reviewed in the context of the proposed legislation which restricts deductibility of dividends and/or imposes tax on dividends. ${ }^{103}$

As the renounced CEE has nothing whatever to do with any business operations conducted by the parent but relates directly to a "property" (i.e. the shares in the capital of the JEC) owned by the parent, it is arguable that the parent is entitled to deduct the renounced $\mathrm{CEE}$ in computing its income from property exclusively, before deducting any such CEE from its business income. On the other hand, if the parent chooses, it is arguable that it may not be required to deduct any of the renounced $\mathrm{CEE}$ in computing any of its income from either its business or property at the stage of income determination contemplated in paragraph 3(a) of the Income Tax Act. Rather, the parent may argue that it is entitled to defer claiming those deductions until the stage of income determination contemplated in paragraph 3(c). The effect of this conclusion would be that if the parent computes its income in this fashion, it is able to deduct the renounced CEE from the aggregate of its income from business and its income from property, rather than being required to deduct the renounced $\mathrm{CEE}$ exclusively from its business income before deducting such $\mathrm{CEE}$ from its income from property.

A Canadian-controlled private corporation having investment income plus up to $\$ 200,000$ of active business income in a particular year would prefer to use renounced CEE to offset its investment income, which is taxed at a higher initial rate in the corporation than its active business income. On the other hand, a Canadiancontrolled private corporation having investment income and more than $\$ 200,000$ of active business income in a particular year may not wish to reduce its investment

102. This assumes that the proposed taxes or dividends on preferred shares set out in the 18 June 1987 Tax Reform White Paper and in draft legislation tabled on 21 April 1988 would be inapplicable in the circumstances.

103. Se' draft legislation released on 21 April 1988. 
income with renounced CEE, because dividend refunds are available from investment income, whereas active business income that is taxed at the higher rate and is distributed to shareholders bears an element of double taxation. Such a corporation would presumably prefer to apply the renounced CEE to reduce its active business income which is taxed at the higher rate.

On an acquisition of control, the expenses of the shareholder corporation become streamed and will be lost unless the shareholder is the parent corporation of a $100 \%$ owned subsidiary which in turn owns resource properties. In any event, the subsidiary will be entitled to renounce income to its parent for purposes of the successor rules. ${ }^{104}$

\section{FLOW-THROUGH SHARES}

The flow-through share regime was substantially revised in 1987 . The basic change was to permit corporations to renounce expenses to persons subscribing for shares without the necessity of those persons actually "incurring" the expenses. Along with such amendments came more refinements to the rules which are designed to limit or restrict deductions in many circumstances and to require a greater level of reporting to and review by the Minister of National Revenue.

\section{Qualifying Shares}

The basic terms of a flow-through share arrangement may be discerned from the definition of "flow-through share". 105 The essential terms of a flow-through share agreement are as follows:

(a) the agreement must concern the share of the capital stock of a corporation:

(b) the corporation must be a "principal-business corporation"; 106

(c) the issue of the share must be to a person pursuant to an agreement in writing entered into between the person and the corporation; ${ }^{107}$

(d) the corporation must agree to incur CEE, CDE or COGPE in an amount not less than the consideration for which the share is to be issued;

(e) the expenditure must be made within the period which commences on the day of execution of the agreement and ends 24 months after the end of the month in which the agreement is signed;

(f) the corporation must agree to renounce in prescribed form an amount of CEE, CDE or COGPE which does not exceed the consideration received;

(g) the renunciation must be made within the noted 24 month period or within 30 days thereafter;

(h) for these purposes, a "share" will include a right to have such share issued and any interest in such a share acquired by a person pursuant to such an agreement, i.e. rights or warrants, will also qualify as flow-through shares provided all the other conditions apply; and

(i) the share which is the subject of such an agreement may not be a "prescribed share", as discussed below.

104. See also supra n. 1, ITA paras. $66.7(10)(\mathrm{g})$ and (h).

105. Id. para. $66(15)(\mathrm{d} .1)$.

106. Defined id. para. $66(15)(\mathrm{h})$.

107. For these purposes, a partnership is defined as a person pursuant to ITA sub-s. 66(16). Note that an agreement between a purchaser and an original subscriber is not a qualifying agreement. 


\section{Prescribed Shares}

The definition of a prescribed share as found in Draft Regulation section 6202.1 first released on December 16, 1987 (and re-released on July 18, 1988) is comprehensive and, generally speaking, will include shares which are not true common shares.

The specific rules "prescribe" shares where: dividends are fixed or limited; amounts payable on redemption or dissolution are fixed or limited; the shares are convertible (or exchangeable) into non-qualifying shares; the corporation has the obligation to reduce paid-up capital or a person has an obligation to provide any form of assistance or loss guarantee; the corporation or a specified person may reasonably be expected to acquire or cancel the share or provide a form of loss guarantee within 5 years of issue; it may reasonably be expected that amendments will be made to the share terms or related agreements within 5 years which would result in the share being a prescribed share; the number of shares to be issued is determined by reference to the value of the shares 60 days after the agreement is entered into; or the corporation or a specified person provided assistance with respect to the acquisition of the share.

\section{What Can Be Renounced}

As noted above, the amount of $\mathrm{CEE}, \mathrm{CDE}$ and $\mathrm{COGPE}^{108}$ to be renounced may not, in the aggregate, exceed the amount for which the share has been issued. However, the amount which the corporation is entitled to renounce is subject to other rules. ${ }^{109}$ For one, the amount to be renounced is reduced by any "assistance" 110 which the corporation has received, is entitled to receive or may reasonably be expected to receive and which may reasonably be related to expenses to which the renounced $\mathrm{CEE}$ or CDE is related. The amount that can be renounced is also reduced by prescribed Canadian Exploration and Development Overhead Expenses. "' (It is not clear whether a corporation can allocate such expenses to CEE or CDE which is not renounced.) The amounts to be renounced may not exceed a corporation's Cumulative CEE pool, Cumulative CDE pool or Cumulative COGPE pool as of the effective date of the renunciation.

As noted above, the renunciation must be made within a required period of time. It is generally conceded that the best evidence of having made a renunciation is to actually sign and file the appropriate prescribed form. It is possible to make a renunciation by passing a directors' resolution or taking other action which clearly demonstrates the renunciation; however, the safest practice appears to be to file the form. The effective date of the renunciation is not necessarily the date on which the form is signed. This means that a corporation might file a renunciation form in February with the renunciation effective as of the December 31 of the preceding year. This would allow investors to claim deductions in computing their income for that preceding year.

108. While it is possible to renounce CEE, CDE and COGPE, there is a perception that it is only appropriate to renounce CEE to public subscribers. This is due to the uncertain present value of $\mathrm{CDE}$ and because undeducted Cumulative CDE and Cumulative COGPE are lost on the death of a taxpayer.

109. Supra n. I, ITA sub-ss. 66(12.6), (12.62) and (12.64).

I10. Id. para. 66(15)(a.1).

111. Supra n. 27, ITR s. 1206. 
Until recently, it has been a requirement that expenses be incurred before the end of a particular year to be eligible for renunciation in that year. The rules were modified with respect to the mining industry and, pursuant to recent changes, similar treatment is now given to the oil and gas industry. This means that expenses incurred within 60 days after the end of a calendar year may be renounced effective as of the preceding calendar year where the agreement was entered into before the end of the year, the corporation and the person dealt at arm's length during the 60-day period and prescribed forms are filed within 90 days of the end of the year. This rule applies only to CEE. ${ }^{112}$

\section{Tax Characteristics of Flow-Through Shares}

Pursuant to the rules in section 66.3, flow-through shares are deemed to have a cost of nil and the paid-up capital of these shares is reduced by approximately $50 \%$ of the amount that would otherwise be booked as paid-up capital. ${ }^{113}$

Because the cost of a flow-through share is deemed to be nil, there is now a perceived disincentive to flow-through share financing unless the share can be issued in connection with an enhanced depletion rate, or an incentive grant, or unless the capital gains exemption will apply to the subscriber on disposition of the share. ${ }^{114}$ This can be seen from the following examples:

\section{TABLE 7 \\ EXAMPLES FOR 1987 AND 1988}

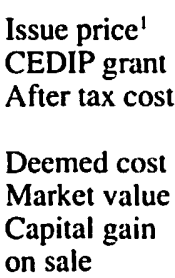

AFTER TAX PROFIT (LOSS):

Without exemption

With exemption ${ }^{3}$

\begin{tabular}{crc} 
& 1987 & \\
\hline 1.60 & $\$ 1.40$ & $\$ 1.40$ \\
$\overline{.80}$ & -.70 & .46 \\
& $.47^{4}$
\end{tabular}

nil nil nil

$\begin{array}{lll}1.00 & 1.00 & 1.00\end{array}$

$\begin{array}{lll}1.00 & 1.00 \quad 1.00\end{array}$

\begin{tabular}{|c|c|c|}
\hline & 1988 & \\
\hline$\$ 1.40$ & $\$ 1.30$ & $\$ 1.20$ \\
\hline - & $.43^{5}$ & - \\
\hline .77 & .48 & .66 \\
\hline
\end{tabular}

nil nil nil

$\begin{array}{lll}1.00 & 1.00 & 1.00\end{array}$

$\begin{array}{lll}1.00 & 1.00 \quad 1.00\end{array}$

Notes to Table 7:

1. The issuer receives a premium on issue but at the same time loses all deductions and any grants renounced. The propery is effectively double taxed. as the issuer does not have a basis in the property acquired and the shareholder has no basis in his shares.

112. Specifically, expenses described in supra n. I. ITA sub-paras. 66.1(6)(a)(i). (ii.l) or (iii): sec supra n. 71, Draft ITA. para. 66(12.66)(b).

113. This rule was enacted in conjunction with the capital gains exemption and was designed to ensure that repurchase of a flow-through share would result, at least in part, in a deemed dividend rather than a capital gain.

114. Until 30 June 1988, an enhanced depletion is available to the mining industry in the form of the Mining Exploration Depletion Allowance ("MEDA") as described in supra n. 27. ITR s. 1203. The Minister of Finance announced on 3 May 1988 that this allowance will now be reduced at the end of 1988 and that a $162 / 3 \%$ allowance will be permitted for 1989 . The oil and gas industry has the benefit of the Canadian Exploration and Development Incentives Program and Canadian Exploration Incentive Program, discussed infra at Parts XII and XIII. 
2. The chart assumes approximate tax rates in 1987 of $50 \%$ and in 1988 of $45 \%$.

3. The capital gains exemption is now limited to a $\$ 100,000$ cumulative gains limit and is to be reduced by an investor's "CNIL" account [i.e.. Canadian Net Investment Loss: see ITA subsection $110.6(1)$ for 1988 and subsequent years].

4. Where grants are renounced to investors, the amount of CEE or CDE renounced is commensurately reduced.

5. CEDIP grants will reduce to $25 \%$ after October 1,1988 , although CEIP grants at a $30 \%$ rate may be available.

\section{New Administrative Requirements}

The new flow-through share rules also require a corporation to file its selling instrument before the last day of the month following the earlier of the month in which the agreement to issue the shares is entered into and the month in which the selling instrument is first delivered to a potential investor. ${ }^{115}$ The corporation is then assigned a number and must use the same number on the various renunciation forms required. ${ }^{116}$ Where a renunciation is made to a partnership, additional forms must be completed and filed. ${ }^{117}$ These rules now permit investigation by the Minister with respect to any amounts renounced and permit the Minister to verify such items. Finally, there is a provision which effectively permits the Minister to cause amounts renounced to be reduced or reclassified as required. ${ }^{18}$

\section{PARTNERSHIPS}

Both general and limited partnerships are commonly used to pass deductions out to participants. To summarize, a partnership's income is calculated as if it were a separate person and any resulting income or loss is allocated to partners according to the partnership agreement. The partnership must take into account Capital Cost Allowance deductions and resource allowance, but deductions and credits for CEE, CDE, COGPE, FEDE and depletion are allocated directly to partners who are members of the partnership at the end of its fiscal period. ${ }^{119}$ Investment tax credit is allocated directly to partners. ${ }^{120}$

In 1986, amendments were introduced to restrict allocations of losses and ITCs to limited partners in excess of amounts "at risk". Draft amendments tabled April 13, 1988 (enacted on September 13, 1988) will extend similar restrictions to resource expenditures. ${ }^{121}$ This effectively restricts limited partnerships from financing exploration or development costs, as the resulting deductions may be restricted in the hands of their limited partners.

\section{CANADIAN EXPLORATION AND DEVELOPMENT INCENTIVE PROGRAM ACT (“CEDIP ACT")}

The CEDIP Act and various publicly-announced proposals 122 provide for an incentive at the rate of $331 / 3 \%$ of eligible expenses incurred after March 31, 1987

115. Supra n. 1, ITA sub-s. 66(12.68).

116. Id. sub-s. 66(12.7).

117. Id. sub-s. 66(12.69)

118. Id. sub-s. 66(12.73). Where $\mathrm{CDE}$ is reclassified as $\mathrm{CEE}$, the renunciations are automatically corrected as of the time of reclassification: see para. $66.1(9)(d)$.

119. Id. sub-paras. 66(15)(e)(iv), 66.l(6)(a)(iv), 66.2(5)(a)(iv), 66.4(5)(a)(ii) and supra n. 27, ITR sub-s. 1206(3).

120. Id. ITA sub-s. 127(8).

121. Supra n. 71, Draft ITA s. 66.8 .

122. Supra n. 22; see also Minister of Energy, Mines and Resources Canada, "Press Release" ( 30 September 1988). 
until September 30,1988, at the rate of $25 \%$ of eligible expenses from October 1 , 1988 to June 30,1989 and at the rate of $162 / 3 \%$ of eligible expenses from July 1,1989 to December 31,1989 . The maximum amount of eligible expenses is $\$ 10$ million and this limit must be shared among all associated persons. Some of the specific provisions of this legislation are noted below.

\section{A. QUALIFIED PERSONS}

The CEDIP Act provides that only a "person" may apply for an incentive and this, by implication, suggests that a partnership may not apply. ${ }^{123}$ However, the Regulations permit one of the partners to apply for the incentives on behalf of each partner. ${ }^{124}$ This provision enhances the program, as the $\$ 10$ million annual limit is allocated to each partner of the partnership on an individual basis, although a partner would have to share the limit with any parties with which he was associated for purposes of the Act. With respect to a trust, only the trustee is considered to be a qualified person able to make application for incentives. ${ }^{125}$

All other legal persons are "qualified" for purposes of the CEDIP Act except for the tax exempt persons enumerated in the Regulations. ${ }^{126}$ One unique "exception to the exception" is that tax exempt municipal corporations will qualify if they paid tax pursuant to the Petroleum and Gas Revenue Tax Act before April 1, 1987. 127

\section{B. ELIGIBLE EXPENSES}

With a few variations, eligible expenses are defined in substantially the same manner as CEE and CDE are defined for income tax purposes, although there is no requirement that the categories of expense be distinguished for purposes of the CEDIP Act. ${ }^{128}$

There are numerous rules which qualify and limit incentives with respect to geological, geophysical and geochemical expenses. These rules include disallowance of certain seismic processing expenses, ${ }^{129}$ requirements that notice be given to the Minister prior to certain programs being conducted, ${ }^{130}$ restriction of expenses incurred with limited recourse debt ${ }^{131}$ and certification requirements as to the technical merit of certain programs. ${ }^{132}$ Other rules require that a seismic broker advertise the sale of his wares on terms not inconsistent with the terms on which such sales normally take place. ${ }^{133}$

There is also a long list of non-eligible expenses, ${ }^{134}$ which include expenses outside the ambit of the program, expenses which are considered unreasonable and expenses which constitute overhead. Expenses outside the ambit of the program

123. Id. s. 4; see Information Circular No. IC-3.

124. Canada Exploration and Development Program Regulations, SOR/87-514, as am. (referred to herein as "CEDIP Regs."), s. 22.

125. Id. sub-s. $3(5)$

126. Id. sub-s. $3(2)$.

127. Id. sub-s. 3(3). It is understood that this exemption was made as a result of lobbying by the City of Medicine Hat.

128. Id. sub-s. 4(1); see Information Circular No. IC-5.

129. Id. sub-s. $4(2)$.

130. Id. para. 4(3)(f).

131. Id. s. 20; see also para. 4(3)(b).

132. Id. paras. $4(3)(\mathrm{c})$, (d) and (e).

133. Id. para. $4(3)(\mathrm{g})$.

134. Id. sub-s. $5(1)$. 
include those incurred on wells spudded before April 1, 1987; expenses which qualify for incentives pursuant to the Petroleum Incentive Program Act; expenses which are eligible for investment tax credit, depletion or capital cost allowance; and interest expenses. Expenses which are considered unreasonable include certain costs subject to a guarantee arrangement; expenses in respect of aggravated or exemplary damages; expenses eligible for reimbursement; fines or penalties; expenses incurred to terminate contracts; payments made to related parties in excess of fair market value and any otherwise unreasonable expenses. ${ }^{135}$ Expenses in respect of Canadian Exploration and Development Overhead Expense are specifically defined in the Schedule to the Regulations in a broad manner to exclude the general overhead expenses from the incentive base, but such that specific overhead expenses relating to the site where activities are being conducted will continue to qualify. ${ }^{136}$ Where the taxpayer does not operate the well, he is entitled to deduct a standard operator's fee, and where the taxpayer does operate the well, he may include an allowance for internal overhead. ${ }^{137}$

\section{ANNUAL EXPENSE LIMIT}

A recent announcement by the Minister of Energy, Mines and Resources indicates that the fiscal year for purposes of this Act is to be changed to the calendar year as opposed to March 31, with the proviso that in certain circumstances an applicant may elect to apply for incentives on expenses incurred between January 1, 1989 and March 31, 1989 and allocate the expenses to the period ending December 31, 1988. This exception will only apply where the applicant was an active oil and gas company immediately prior to May $3,1988 .^{138}$

The annual expense limit must be shared among "associated persons". The association definitions are patterned after those in the Income Tax Act, ${ }^{139}$ and associate related individuals, ${ }^{140}$ individuals and the corporations they control, ${ }^{141}$ and corporations subject to common control. ${ }^{142}$ There is a provision exempting certain active public corporations from association where 10 per cent of the corporation's shares are held by the public. ${ }^{143}$ In addition, there are rules which associate persons with "inactive corporations" where the persons own at least 10 per cent of the voting shares of the corporation. These rules are designed to prevent taxpayers from magnifying access to the CEDIP incentives by creating other corporations after April $1,1987 .{ }^{144}$ The Minister also has the discretion to associate any two persons where he is satisfied that the separate existence of the persons is not solely for the purpose of carrying on their businesses in the most effective manner and that one of the

135. Id. sub-ss. $5(1)$ and (2).

136. Id. sub-s. 5(1) and Schedule A.

137. Id. Schedule A.

138 Energy, Mines and Resources Canada, "Release" (3 May 1988).

139. Supra n. 124, CEDIP Regs. s. 2.

140. Id. s. 8.

141. Id. s. 9.

142. Id. s. 10. Cf. supra n. 1, ITA paras. 256(1)(d) and (e), and B.B. Fast \& Sons Distributors Limited 86 D.T.C. 6106 (Fed.C.A.). There are also rules which treat options as equivalent to share ownership: see CEDIP Regs. para. $2(8)(b)$, and which associate the predecessors to an amalgamated corporation: see CEDIP Regs. sub-s. 10(2).

143. Supra n. 124, CEDIP Regs. S. 11. This is apparently patterned after the Alberta Royalty Tax Credit rules.

144. Id. s. 12. An "inactive corporation" is defined as one not in existence prior to 31 March 1987 or which did not incur eligible expenses in the 12-month period ending 31 March 1987. 
reasons for their separate existence is to increase the amount of payments to which they would otherwise be entitled. ${ }^{145}$

\section{SPECIAL SITUATIONS}

Where a joint exploration corporation has the right to renounce expenses for purposes of the Income Tax Act, it is to allocate eligible expenses for purposes of the CEDIP Act to its shareholders. ${ }^{146}$ The joint exploration corporation remains entitled to the CEDIP grant, but may claim on the same basis that the shareholder might have claimed it if incurred directly. ${ }^{147}$ When the grant is received by the joint exploration corporation, it does not automatically belong to the shareholder corporation and would have to be paid to the shareholder in the normal manner. ${ }^{148}$

Where corporations issue flow-through shares, they may either retain the incentive grants in the corporation or else apply for and receive the grants on behalf of the shareholders. In either case, the expenses incurred will be counted for the purposes of the $\$ 10$ million annual expenditure limit of the corporation. ${ }^{149}$ CEDIP grants are assignable, and reference should be made to specific procedures noted in Information Circular No. IC-6.

\section{E. ANTI-AVOIDANCE PROVISIONS}

In addition to the anti-avoidance provisions noted previously, there are specific rules which limit eligibility in other situations. The Regulations provide that expenses for services or property are considered to be incurred when the services are rendered or during the period of use or existence of the right to use the property. ${ }^{150}$ Where individuals are related but not associated, the expenses are, for purposes of the annual expenditure limit, considered to be incurred by each of the parties. ${ }^{151}$ Expenditures incurred by a limited partnership in circumstances where the qualifying party ends up owning shares of a corporation may be deemed to result in the corporation's annual expenditure limit being reduced, much as it would have been had the corporation issued flow-through shares. ${ }^{152}$ Expenses incurred under limited recourse financing arrangements are allocated to the party providing the financing for purposes of the annual expenditure limit. ${ }^{153}$ Expenses incurred under arrangements which are designed to shift the value of the CEDIP grant to another person are allocated to that person for the purpose of the annual expenditure limit. ${ }^{154}$ Section 28 of the Act provides that where the Minister is of the opinion that a person has done anything which lacks a substantial business purpose in order to increase the amount of grants payable, or which improperly, unduly or artificially increases the amount of payments, the Minister may refuse to make the payment or may recover same if already paid.

145. Stupra n. 22, CEDIP Act s. 6. See also supra n. 124, CEDIP Regs. ss. 15, 17, 18 and 19.

146. Id., CEDIP Act s. 7.

147. Id. sub-s. 7(2). This may have the effect of increasing the annual expenditure limit.

148. Cf. Information Circular IC-3 para. 5 , which appears to be incorrect.

149. Supra n. 22, CEDIP Act, s. 8.

150. Supra n. 124, CEDIP Regs. s. 6 . This is to prevent the taxpayer from claiming grants on certain prepaid costs.

151. Id. s. 15 .

152. Id. s. 17

153. Id. s. 18.

154. Id. s. 19. 


\section{CANADIAN EXPLORATION INCENTIVE PROGRAM (“CEIP”)}

On May 3, 1988, the Minister of Energy, Mines and Resources announced a follow-up program to CEDIP. This provides that $30 \%$ of eligible exploration expenses (as opposed to exploration and development expenses) will be qualified for an incentive under terms similar to those provided in the CEDIP Act, although this grant will only apply to exploration expenses incurred under a flow-through share agreement where the corporation and the investor deal at arm's length. Where the corporation elects to receive a CEIP grant, it will not be entitled to receive a CEDIP grant on the same expenditure and the same annual business limit will apply to both programs. This program begins October 1, 1988 for oil and gas exploration and January 1, 1989 for mineral exploration. The rate of $30 \%$ has been set for a period of two years and is to be adjusted thereafter according to market conditions. ${ }^{155}$ This announcement is in keeping with the statement made in the White Paper on Tax Reform published June 18,1987, where the government indicated that adjustments in the form of non-tax assistance would be considered from time to time.

\section{AUTHOR'S UPDATE}

Since this paper was written in May, 1988, the amendments to the Income Tax Act which are referred to herein as the "draft legislation released on April 13,1988" have been enacted. They were enacted on September 13, 1988, as S.C. 1988, c. 55.

155. Supra n. 138. The CEIP Act was enacted on 28 June 1988 and Draft Regulations thereunder were released on 25 August 1988. 